\title{
HUBUNGAN ANTARA PENGETAHUAN AKSEPTOR KB PIL DENGAN KEPATUHAN MINUM PIL KB DI BIDAN PRAKTEK SWASTA TITIN WIDYANINGSIH PONTIANAK TAHUN 2020
}

\section{Telly Katharina ${ }^{1}$, Denny Pebrianti ${ }^{2}$}

\author{
Akademi Kebidanan Panca Bhakti Pontianak \\ Email korespondensi: akbidpbpontianak@gmail.com
}

\begin{abstract}
Abstrak
Penggunaan alat kontrasepsi merupakan salah satu variabel yang mempengaruhi fertilitas (kehamilan). Alat kontrasepsi yang sering digunakan salah satunya dengan menggunakan pil KB. Pil KB akan efektif dan aman apabila digunakan secara benar dan konsisten. Kegagalan akseptor KB pil oral dapat disebabkan karena kurangnya kepatuhan akseptor dalam mengkonsumsi pil KB tersebut. Tujuan penelitian ini adalah untuk mengetahui apakah ada hubungan antara pengetahuan akseptor KB Pil dengan kepatuhan minum Pil KB di Bidan Praktek Swasta Titin Widyaningsih Pontianak tahun 2020. Desain penelitian ini menggunakan metode survey analitik dengan pendekatan cross sectional. Populasi pada penelitian ini sebanyak 161 orang dan sampel sebanyak 40 orang akseptor KB pil. Hasil penelitian ini menjelaskan bahwa akseptor KB yang berpengetahuan baik dan memiliki tingkat kepatuhan yang tinggi dalam meminum pil KB ada sebanyak 2,5\%. Akseptor KB yang berpengetahuan cukup dan tingkat kepatuhannya sedang dalam meminum pil KB ada sebanyak $25 \%$. Akseptor KB yang pengetahuannya kurang dan tingkat kepatuhannya rendah dalam meminum pil KB sebanyak 7,5\%. Berdasarkan perhitungan dengan menggunakan chi square didapatkan nilai $\mathrm{X}$ hitung lebih kecil dari $\mathrm{X}$ tabel yang artinya Ho diterima sebab 3,01 $<9,488$. Dengan demikian hasil akhir dari pengujian data dinyatakan bahwa tidak ada hubungan antara pengetahuan akseptor KB Pil dengan kepatuhan minum Pil KB di Bidan Praktek Swasta Titin Widyaningsih Pontianak tahun 2020. Harus dilakukan adalah upaya penyadaran pada akseptor KB Pil melalui pemberian informasi akan pentingnya rutinitas dalam minum Pil KB.
\end{abstract}

Kata Kunci: Pengetahuan, Akseptor KB Pil, Kepatuhan

\section{Abstract}

The use of contraceptives is one of the variables that affect fertility (pregnancy). One of contraception that often used is using birth control pills. Birth control pills will be effective and safe if used correctly and consistently. The failure of oral pill birth control acceptors can be caused by the lack of acceptor compliance in taking the birth control pill. The purpose of this study was to determine whether there is a relationship between the knowledge of birth control pill acceptors and adherence to taking birth control pills in the private practice midwife of Titin Widyaningsih in Pontianak 2020. The design of this study used an analytical survey method with cross sectional approach. The population in this study was 161 people and sample as many as 40 people. The results of this study explain that family planning acceptors who are well-informed and have a high level of compliance in taking birth control pills are as much as 5\%. Family planning acceptors with sufficient knowledge and moderate level of compliance in taking birth control pills are $27.5 \%$. Family Planning acceptors who lack knowledge and low levels of adherence in taking birth control pills are $7.5 \%$. Based on calculations using chi square obtained $X$ count value is smaller than $X$ table which means that Ho is accepted because 3.01 $<9,488$.Thus the final results of the test data stated that there was no relationship between the knowledge of the acceptors of the Pill and the compliance with taking the Pill in the private practice midwife of Titin Widyaningsih in Pontianak 2020. Must be done is an effort to raise awareness in the Family Planning Pill acceptor through providing information on the importance of routine in taking the Family Planning Pill.

Keywords: Knowledge, Pill Acceptor of Family Planning, Adherence

\section{Pendahuluan}

Penggunaan alat kontrasepsi merupakan salah satu variabel yang mempengaruhi

\footnotetext{
${ }^{1}$ Dosen Akademi Kebidanan Panca Bhakti Pontianak

${ }^{2}$ Dosen Akademi Kebidanan Panca Bhakti Pontianak
}

fertilitas (kehamilan). Alat kontrasepsi yang sering digunakan salah satunya dengan 
menggunakan pil KB. Pil KB dipergunakan oleh kurang lebih 50 juta akseptor di seluruh dunia. Kenaikan jumlah akseptor diseluruh dunia (Irianto Koes, 2014).

Kenaikan jumlah akseptor terlihat terutama dalam 20 tahun terakhir ini. Di Indonesia diperkirakan kira-kira 60\% akseptor mempergunakan pil KB. Jumlah ini tampaknya akan tetap tinggi dibandingkan dengan jumlah akseptor yang mempergunakan cara kontrasepsi yang lain (Irianto Koes, 2014).

Pil KB merupakan alat kontrasepsi hormonal yang berupa obat dalam bentuk pil yang dimasukkan melalui mulut (diminum), berisi hormon estrogen dan atau progesterone. Pil KB sendiri memiliki 2 jenis, yakni pil KB yang mengandung 2 (dua) hormon atau disebut juga dengan dengan pil KB terpadu (Uliyah Mar'atul, 2010).

Kontrasepsi pil kombinasi adalah pil yang mengandung hormon estrogen dan progesteron dengan dosis tertentu. Hormon di dalam pil ini, sangat mirip dengan hormon estrogen dan progesteron yang ada didalam tubuh wanita. Mekanisme utama pil kombinasi untuk mencegah terjadinya kehamilan adalah dengan menghambat keluarnya sel telur (ovum) dari indung telur (ovarium). Hormon yang digunakan untuk pil kombinasi adalah estrogen (etinil estradiol/EE) dan progesteron (19 nortestoteron atau 17 alfahydroksiprogesteron atau 17 spironolakton) (Nurjasmi Emi, dkk, 2016).
Efektifitas metode kontrasepsi yang digunakan tergantung pada kesesuaian pengguna dengan instruksi. Perbedaan keberhasilan metode juga tergantung pada tipikal penggunaannya (yang terkadang tidak konsisten) dan penggunaan sempurna (mengikuti semua instruksi dengan benar dan tepat (Nugroho Taufan dkk, 2014).

Dengan penggunaan yang benar, hanya terjadi kurang dari 1 kehamilan per 100 perempuan atau kehamilan per 1000 perempuan di tahun pertama penggunaannya. Kontrasepsi pil kombinasi tidak akan mengganggu kembalinya kesuburan karena apabila penggunaan dihentikan, kehamilan dapat terjadi di bulan berikutnya (kecuali bila ditemukan gangguan lainnya). Penggunaan kontrasepsi pil kombinasi tidak dapat menncegah terjadinya infeksi menular seksual (IMS) pada penggunaannya (Nurjasmi Emi, dkk, 2016).

Pil KB akan efektif dan aman apabila digunakan secara benar dan konsisten. Kegagalan akseptor $\mathrm{KB}$ pil oral dapat disebabkan karena kurangnya kepatuhan akseptor dalam mengkonsumsi pil KB tersebut (Prasetyawati Anna, 2012).

Penelitian Anna Prasetyawati (2012) melakukan penelitan dengan judul "Hubungan Pengetahuan Akseptor Tentang Kontrasepsi Pil Oral Kombinasi Dengan Kepatuhan Dalam Mengkonsumsi Pil KB Di Wilayah Desa Margasana Kecamatan Jatilawang Tahun 2012" hasilpeneltian enunjukkan bahwa pengetahuan akseptro tentang kontrasepsi pil oral kombinasi sebagian besar pada kategori 
baik $60 \%$. Dan sebagian besar pada kategori patuh 53,3\%. Terdapat hubungan yang signifikan antara pengetahuan akseptor tentang kontrasepsi pil oral kombinasi dengan kepatuhan dalam mengkonsumsi pil KB.

Hasil penelitian Charisanti Cicilia Sanding (2014), dengan judul penelitian "Hubungan Pengetahuan Ibu Dengan Kepatuhan Minum Pil KB Di Puskesmas Modayag Kecamatan Modayag Kabupaten Bolang Mongondow Timur tahun 2014" hasil penelitian didapatkan 5 responden dengan tingkat pengetahuan baik, tidak patuh pada jadwal minum pil dan 19 responden yang memiliki tingkat pengetahuan yang kurang, tidak patuh pada jadwal minum pil. Kesimpulan ada hubungan antara pengetahuan ibu dengan kepatuhan minum pil KB.

Berdasarkan data yang diperoleh dari Bidan Praktek Swasta Titin widyaningshi Pontianak, jumlah kunjungan perbulan akseptor pil KB pada bulan September 2019 Februari 2020 sebesar 108 akseptor baru dan total keseluruhan akseptor ada sebesar 952 akseptor.

\section{Hasil dan Pembahasan}

Tabel 1. Distribusi Frekuensi Responden Berdasarkan Tingkat Pengetahuan di Bidan Praktek Swasta Titin Widyaningsih

\begin{tabular}{ccc}
\hline Pengetahuan & Jumlah responden (n) & $\begin{array}{c}\text { Persentase jumlah responden } \\
(\boldsymbol{\%})\end{array}$ \\
\hline Baik & 7 orang & $17,5 \%$ \\
Cukup & 26 orang & $65 \%$ \\
Kurang & 7 orang & $17,5 \%$ \\
\hline
\end{tabular}

Berdasarkan studi pendahuluan yang dilakukan penelitian di bidan Praktek Swasta Titin Widyaningsih Pontianak terdapat keluhan yang disampaikan akseptor, pada enam akseptor KB pil, Ny. H dan NY. S mual setelah minum pil KB, Ny. M dan NY. I malas dan bosan minum pil KB, Ny. D dan NY. E malas untuk minum pil $\mathrm{KB}$ setiap hari sedangkan Ny. V mengalami kegagalan dalam minum pil KB sehingga terjadi kehamilan.

Berdasarkan permasalahan diatas peneliti tertarik untuk melakukan peneltian dengan judul " Hubungan Antara Pengetahuan Akseptor KB Pil Dengan Kepatuhan Minum Pil KB di Bidan Praktek Swasta Titin Widyaningsih Pontianak tahun 2020.

\section{Metode}

Desain penelitian ini menggunakan metode survey analitik dengan pendekatan cross sectional. Penelitian dilakukan di Bidan Praktek Swasta Titin Widyaningsih Pontianak. Populasi pada penelitian ini sebanyak 161 orang peneliti mengambil 25\% dari populasi akseptor KB pil sebanyak 40 orang. 
Berdasarkan tabel 1 didapatkan hasil tingkat pengetahuan akseptor KB Pil bahwa sangat sedikit dari responden yaitu sebanyak 7 orang dengan presentase jumlah responden sebesar
$17,5 \%$ yang berpengetahuan baik sedangkan sebanyak 26 orang $(65 \%)$ responden memiliki tingkat pengetahuan yang cukup.

Tabel 2 Distribusi Frekuensi Responden Berdasarkan Kepatuhan Dalam Mengkonsumsi Pil

KB di Bidan Praktek Swasta Titin Widyaningsih

\begin{tabular}{ccc}
\hline Kepatuhan mengkonsumsi Pil KB & $\begin{array}{c}\text { Jumlah responden } \\
(\mathrm{n})\end{array}$ & $\begin{array}{c}\text { Presentase jumlah responden } \\
(\%)\end{array}$ \\
\hline Tinggi & 7 orang & $17,5 \%$ \\
Sedang & 15 orang & $37,5 \%$ \\
Rendah & 18 orang & $45 \%$ \\
\hline
\end{tabular}

Tabel diatas menunjukkan hasil tingkat kepatuhan akseptor dalam minum Pil KB bahwa sangat sedikit dari responden yaitu sebanyak 7 orang dengan presentase jumlah responden sebesar $17,5 \%$ yang kepatuhan tinggi dalam minum Pil KB.

Tabel 3 Hubungan Antara Pengetahuan Akseptor KB Pil Dengan Kepatuhan Minum Pil KB

\begin{tabular}{|c|c|c|c|c|c|c|c|c|}
\hline \multirow{3}{*}{ Pengetahuan } & \multicolumn{6}{|c|}{ Kepatuhan Akseptor Minum Pil KB } & \multirow{3}{*}{$\mathrm{P}$ value } & \multirow{3}{*}{ OR } \\
\hline & \multicolumn{2}{|c|}{ Tinggi } & \multicolumn{2}{|c|}{ Sedang } & \multicolumn{2}{|c|}{ Rendah } & & \\
\hline & $\mathrm{N}$ & $\%$ & $\mathrm{~N}$ & $\%$ & $\mathrm{~N}$ & $\%$ & & \\
\hline Baik & 1 & 2,5 & 3 & 7,5 & 3 & 7,5 & & \\
\hline Cukup & 4 & 10 & 10 & 25 & 12 & 30 & 3,01 & 9,488 \\
\hline Kurang & 1 & 2,5 & 3 & 7,5 & 3 & 7,5 & & \\
\hline
\end{tabular}

Tabel 3 diatas menunjukkan bahwa akseptor KB yang berpengetahuan baik dan memiliki tingkat kepatuhan yang tinggi dalam meminum pil $\mathrm{KB}$ ada sebanyak 2,5\%. Akseptor KB yang berpengetahuan cukup dan tingkat kepatuhannya sedang dalam meminum pil KB ada sebanyak 25\%. Akseptor KB yang pengetahuannya kurang dan tingkat kepatuhannya rendah dalam meminum pil KB sebanyak 7,5\%.

Berdasarkan perhitungan dengan menggunakan chi square didapatkan nilai $\mathrm{X}$ hitung lebih kecil dari $\mathrm{X}$ tabel yang artinya Ho diterima sebab 3,01<9,488. maka dapat disimpulkan tidak ada perbedaan yang signifikan pada pengetahuan responden tentang Pil KB dengan kepatuhan akseptor minum pil KB (tidak ada hubungan antara pengetahuan dengan kepatuhan minum Pil $\mathrm{KB})$.

Berdasarkan dari hasil penelitian didapatkan data pengetahuan yang jarang dimengerti oleh akseptor KB Pil mulai dari jenis - jenis, cara minum, dan syarat - syarat penggunaan. Berdasarkan tabel 1 dapat diketahui bahwa sangat sedikit dari responden $(17,5 \%)$ yang berpengetahuan baik dan kurang dan sebagian besar dari responden (65\%) yang memiliki pengetahuan cukup. 
Hasil penelitian menunjukkan bahwa pengetahuan akseptor tentang kontrasepsi Pil sebagian besar cukup yaitu 26 responden berarti rata - rata responden dianggap mengerti tentang KB Pil dan semua hal yang berhubungan antara lain jenis - jenis, cara minum dan syarat - syarat penggunaan.

Pengetahuan responden yang sebagian besar cukup dapat dipengaruhi oleh pengalaman ibu menggunakan kontrasepsi Pil dalam waktu yang cukup lama. Pengalaman merupakan salah satu faktor yang mempengaruhi tingkat pengetahuan seseorang. Pengalaman yang dimiliki oleh seseorang menyebabkan seseorang mempunyai kemampuan analisis dan sintesis yang baik (Irmayati, 2007).

Hal ini sesuai dengan teori yang diungkapkan oleh Notoatmodjo (2007) dimana pengalaman adalah guru yang baik, demikian bunyi pepatah. Pepatah ini mengandung maksud bahwa pengalaman itu merupakan sumber pengetahuan, atau pengalaman itu merupakan suatu cara untuk memperoleh kebenaran pengetahuan. Oleh karena itu pengalaman pribadi pun dapat digunakan sebagai upaya memperoleh pengetahuan. Hal ini dilakukan dengan cara mengulang kembali pengalaman yang diperoleh dalam memecahkan permasalahan yang dihadapi pada masa yang lalu.

Hasil penelitian ini sejalan dengan penelitian yang dilakukan oleh Fya Firzanah (2013) di Universitas Mayjen Sungkono Mojokerto tentang Hubungan Antara Penegtahuan akseptor KB Pil Dengan
Kepatuhan Mengkonsumsi Di BPS Ny. "TE" Desa Tampongrejo Kecamatan Puri Kabupaten Mojokerto didapatkan hasil bahwa sebagian besar $55 \%$ dari responden berpengetahuan cukup.

Berdasarkan tabel 2 dapat diketahui bahwa sebagian dari responden (45\%) yang memiliki kepatuhan rendah dalam minum Pil KB dan sebagian kecil dari responden $(37,5 \%)$ yang memiliki kepatuhan sedang dalam minum Pil KB.

Hasil penelitian menunjukkan bahwa sebagian dari responden yang memiliki kepatuhan rendah yaitu 18 responden berarti responden minum Pil KB tidak sesuai dengan petunjuk tenaga kesehatan. Responden minum Pil KB tidak secara teratur dan tidak tepat waktu. Keteraturan dalam minum Pil KB dilihat dari minum 1 hari 1 kali, minum pada jam yang sama, bila 1 hari tidak minum Pil KB maka harus di minum di hari berikutnya, bila datang bulan dan Pil KB masih ada maka harus diteruskan minum Pil KB.

Hal ini sesuai dengan teori Depkes (2010) dimana keteraturan minum Pil KB masih memungkinkan akseptor mengalami kehamilan. Hal ini dikarenakan keteraturan pengkonsumsian menyebabkan hormon yang terkandung dalam Pil KB bekerja dengan maksimal. Sehingga memungkinkan akseptor KB Pil tidak mengalami kehamilan yang tidak diinginkan.

Hasil penelitian ini sejalan dengan penelitian yang dilakukan Charisanti Cicilia Sanding (2014) Ilmu Keperawatan Fakultas Kedokteran Universitas Sam Ratulangi 
Manado tentang Hubungan Pengetahuan Ibu

Dengan Kepatuhan Minum Pil KB di

Puskesmas Modayag Kecamatan Modayag

Kabupaten Bolang Mongondow Timur didapatkan hasil bahwa sebagian 54,4\% responden yang tidak patuh dalam mengkonsumsi Pil KB.

Dari hasil penelitian menunjukkan bahwa akseptor $\mathrm{KB}$ yang pengetahuannya baik yang kepatuhannya tinggi minum Pil KB $(2,5 \%)$. Akseptor KB yang pengetahuannya cukup yang kepatuhannya sedang minum Pil KB (25\%). Akseptor KB yang pengetahuannya kurang yang kepatuhannya rendah minum Pil KB (7,5\%). Hasil uji statistik diperoleh nilai Chi square didapatkan nilai Xhitung sebesar 3,01 sedangkan nilai pada tabel Chi square dengan $\mathrm{Db} 4$ dan tingkat kepercayaan 95\% adalah 9,488. Pada penelitian ini $\mathrm{X}$ hitung lebih kecil dari $\mathrm{X}$ tabel yang artinya Ho diterima sebab 3,01 $<9,488$. Dengan demikian hasil akhir dari pengujian data dinyatakan bahwa tidak ada hubungan yang signifikan antara pengetahuan akseptor KB Pil dengan kepatuhan minum Pil KB di Bidan Praktek Swasta Titin Widyaningsih tahun 2015.

Dari hasil penelitian didapatkan hasil sebagian besar akseptor berpengetahuan cukup dan memiliki kepatuhan rendah. Hal ini dipengaruhi oleh faktor lain, pendidikan, pekerjaan, lingkungan dan lain-lain, sehingga kepatuhan dalam minum Pil KB rendah walaupun pengetahuannya cukup.

Hasil penelitian ini tidak sesuai dengan teori Notoatmodjo (2007) dimana pengetahuan merupakan hasil tahu dan ini terjadi setelah orang melakukan pengindraan terhadap suatu obyek tertentu, dari pengalaman dan penelitian terbukti bahwa perilaku yang didasari oleh pengetahuan akan lebih langgeng dari pada perilaku yang tidak didasari oleh pengetahuan.

Hasil penelitian ini juga tidak sesuai dengan teori Azwar (2007) dimana adanya unsur pengalaman yang semula tidak konsisten dengan apa yang diketahui oleh individu akan disusun, ditata kembali atau diubah sedemikian rupa, sehingga tercapai suatu konsistensi. Semakin tinggi tingkat pengetahuan, semakin baik pula ibu minum Pil KB.

Hasil penelitian ini berbeda dengan penelitian yang dilakukan oleh Charisanti Cicilia Sanding di Puskesmas Modayang Kecamatan Modayang Kabupaten Bolang Mongondow Timur Tahun 2014 dengan judul "Hubungan Pengetahuan Ibu Dengan Kepatuhan Minum Pil KB" hasilnya terdapat hubungan antara pengetahuan ibu dengan kepatuhan minum Pil KB di Puskesmas Modayag.

Hasil penelitian yang dilakukan Anna Prasetyawati di wilayah Desa Margasana dengan judul "Hubungan Pengetahuan Akseptor Tentang Kontrasepsi Pil Oral Kombinasi Dengan Kepatuhan Dalam Mengkonsumsi Pil KB", memiliki hasil yang berbeda dengan yang peneliti lakukan. Hasil penelitian yang dilakukan oelh Anna Prasetyawati juga menunjukkan adanya hubungan antara pengetahuan akseptor 
tentang kontrasepsi oral Pil dengan kepatuhan dalam mengkonsumsi Pil KB di wilayah Desa Margasana Kecamatan Jatilawang.

Berdasarkan kedua hasil penelitian tersebut dapat disimpulkan bahwa tingkat pengetahuan akseptor ada hubungan terhadap kepatuhan akseptor dalam minum Pil Kb, dimana semakin baik tingkat pengetahuan akseptor maka semakin patuh dalam minum Pil KB. Namun hasil penelitian yang dilakukan oleh peneliti pada akseptor KB Pil di Bidan Praktek Swasta Titin widyaningsih menunjukkan bahwa tidak adanya hubungan antara pengetahuan akseptor KB Pil dengan kepatuhan minum Pil KB. Hasil penelitian ini sesuai dengan teori Zuhri (2010) seseorang akan cenderung meremehkan suatu kebiasaan ketika pengetahuan tentang kebiasaan tersebut tidak begitu dipahami maka menyebabkan kesadaran akan pentingnya kebiasaan tersebut menjadi berkurang. Di Bidan Praktek Swasta Titin Widyaningsih, pemberian penyuluhan tentang $\mathrm{KB}$ selalu diberikan oleh petugas kesehatan, namun pada hasil penelitian ini menunjukkan bahwa pengetahuan akseptor KB Pil tidak ada hubungannya dengan kepatuhan akseptor dalam minum Pil KB.

\section{Kesimpulan}

Kesimpulan yang dapat diambil dalam penelilitian ini adalah tidak ada hubungan antara pengetahuan akseptor KB Pil dengan kepatuhan minum Pil KB di Bidan Praktek Swasta Titin Widyaningsih Pontianak tahun 2020Pemahaman setiap individu dipengaruhi oleh tingkat pengetahuan yang berbeda.
Tingkat pengetahuan ini dipengaruhi oleh tingkat pendidikan, keteraparan informasi dan pengalaman.

Pemahaman tentang instruksi adalah salah satu faktor yang mempengaruhi ketidakpatuhan. Tidak seorangpun dapat mematuhi instruksi jika seseorang salah paham dengan instruksi yang diberikan. Yang harus dilakukan adalah upaya penyadaran pada akseptor KB Pil melalui pemberian informasi akan pentingnya rutinitas dalam minum Pil KB. Disamping itu hendaknya akseptor KB Pil selalu berkonsultasi dengan tenaga kesehatan seputar KB Pil. Konsultasi rutin bisa menyebabkan akseptor KB Pil bisa patuh dalam minum Pil KB.

\section{Daftar Pustaka}

Prasetyawati Anna, dkk.2012. Hubungan Pengetahuan Akseptor Tentang Kontrasepsi Pil Oral Kombinasi Dengan Kepatuhan Dalam Mengkonsumsi Pil Kb di Wilayah Desa Margasana Kecamatan Jatilawang Tahun 2012. Akademi Kebidanan YLPP Purwokerto

Arum Setya, N.D dkk, 2008. Panduan Lengkap Pelayanan KB Terkini. Yogyakarta: Mitra Cendikia Ofsett

Azwar, 2007. Sikap Manusia dan Pengukurannya. Jakarta: PT. Rineka

Degresi. 2005. Ilmu Perilaku Manusia. Jakarta: PT. Rineka Cipta

Dinas Kesehatan Provinsi Kalimantan Barat 2011. http://www.depkes.go.id. Profil Kesehatan Provinsi Kalimantan Barat 2011. di akses 1 April 2015, 09.19 WIB

Effendy. 2005. Keperawatan Keluarga. Jakarta: EGC 
Handayani, Sri. 2010. Buku Ajar Pelayanan Keluarga Berencana. Yogyakarta: Pustaka Rihama

Irianto Koes, 2014. Pelayanan Keluarga Berencana Dua Anak Cukup: Bandung. Alfabeta

Irmayanti,

2007. http://id.wikipedia.org/wiki/pengetahu an. diakses 22 Mei 2015, 19.00 WIB

Kementerian Kesehatan RI 2011. http://www.kemkes.go.id Profil Kesehatan Indonesia 2012. Di akses 7 februari 2015, 9.27 WIB

Morisky D. E, Ang a, Marie K. Harry J W. 2008. Predictive Validity of a Medication Adherence Measure in an Outpatient Setting. The journal of Clinical Hypertension.

Niven. 2008. Psikologi Kesehatan : Pengantar Untuk Perawat Dan Profesional. Jakarta: EGC

Notoatmodjo, 2003. Metodelogi Penelitian Kesehatan. Jakarta: Rineka Cipta 2005. Metodologi Penelitian Kesehatan. Jakarta: Rineka Cipta

2010. Promosi Kesehatan Ilmu dan Seni. Jakarta: Rineka Cipta

Nursalam.2008. Konsep dan Penerapan Metodologi Penelitian Ilmu Keperawatan. Jakarta: Salemba Medika

Pranoto Ibnu. 2007. Ilmu Kebidanan. Yogyakarta: Yayasan Bina Pustaka Sarwono Prawirohardjo

Rekkiyuskal. 2013. Cara Memperoleh Pengetahuan.

http://Rekkiyuskal.blogspot.com, diakses: 7 April, 21.37 WIB

Riskesdes Kementerian Kesehatan RI 2013. http://www.kemkes.go.id Profil Kesehatan Indonesia 2012. Di akses : 1 April 2015, 08.50 WIB
Rismawati Sariestya.2012 Nmet Need: Tantangan Program Keluarga

Berencana Dalam Menghadapi Ledakan Penduduk Tahun 2030. Mahasiswa Magister Kebidanan Fakultas Kedokteran UNPAD Bandung. Diakses Tgl 31 Maret Jam $08.35 \mathrm{Http} / / /$ Pustaka.Unpad.Ac.Id/Wp Content/Uploads/2014/10/ArtikelUnmet-Need.Pdf

Sanding.C.C,Dkk.2014. Hubungan Pengetahuan Ibu Dengan Kepatuhan Minum Pil Kb Di Puskesmas Modayag Kecamatan Modayag Kabupaten Bolaang Mongondow Timur. Universitas Sam Ratulangi Manado

Santoso Iman. S. 2007. Psikologi Umum. Bandung: PT Remaja Rosdakarya

Setiawan, A. dkk. 2010. Metodologi Penelitian kebidanan. Nuha Medika. Jakarta

Sugiyono, 2011. Metode Penelitian Kuantitatif, Kualitatif, dan R\&D. Bandung: AFABETA, cv.

Suharsimi Arikunto, 2010. Prosedur Penelitian Suatu Pendekatan Praktek Edisi Revisi V. Jakarta: Rineka Cipta

Suparyanto. 2012. Konsep Dukungan Keluarga.http://konsep-dukungankeluarga.blogspot.com. diakses 09 April 2015, 19.23 WIB

Supyanti N.A,Dkk.2012. Gambaran Faktor Karakteristik Dan Pengetahuan Pria Mengenai Metode Operasi Pria (MOP) Di Desa Cisarandi Kecamatan Warungkondang Kabupaten Cianjur. Http://Www.Jurnalpendidikanbidan.Co m diakses 24 Maret 09.01 WIB

Suratun, SKM dkk, 2008. Pelayanan Keluarga Berencana \& Pelayanan Kontrasepsi : Jakarta Timur. Trans Info Media

Terrence Blashke.L.O. 2005. Adherence to Medication. The New England Journal of Medicie. 
Uliyah Mar'atul, 2010. Panduan Aman Dan Sehat Memilih Alat KB: Yogyakarta.

PT Bintang Pustaka Abadi 